\title{
FIRST INTERNATIONAL WORKSHOP ON COMPUTATIONAL LATIN DIALECTOLOGY
}

\author{
April 7-8, 2016, Research Institute for Linguistics, \\ Hungarian Academy of Sciences, Budapest, Hungary
}

Present fascicle of the Acta Antiqua Academiae Scientiarum Hungaricae contains the elaborated, revised and peer-reviewed versions of the papers presented at the First International Workshop on Computational Latin Dialectology (April 7-8, 2016, Research Institute for Linguistics, Hungarian Academy of Sciences, Budapest, Hungary, cf. http:// www.nytud.hu/conf/cldworkshop2016.html) organized in the framework of the projects "Lendület ('Momentum') Research Group for Computational Latin Dialectology" (Research Institute for Linguistics, Hungarian Academy of Sciences, cf. http://www. nytud.hu/depts/fu/indexlendulet.html) and OTKA (Hungarian Scientific Research Fund) No. K 108399 "Computerized Historical Linguistic Database of Latin Inscriptions of the Imperial Age" (Eötvös Loránd University Budapest, cf. http://lldb.elte.hu/).

This Workshop was realized as the first one in a series of workshops to be organized in Budapest each year (at least until 2020). The aim of the series is to discuss current problems and results of Latin Dialectology as evidenced from inscripitons and connected to the work with the Computerized Historical Linguistic Database of Latin Inscriptions of the Imperial Age in the framework of the Lendület ('Momentum') Research Group for Computational Latin Dialectology. Not only fellows of the research group participated, but also other collaborators and data collectors involved in the project, including those who live and work outside Hungary, and even other experts interested in the research topic.

Accordingly, on the two days (Thursday and Friday) of the 2016 Workshop, papers were presented by Béla Adamik ("Potential Greek Influence on the Vulgar Latin Sound Change $[b]>[\beta]$ : Dialectological Evidence from Inscriptions"), Andrea Barta ("A Letter to the Netherworld. The Third Curse Tablet from Aquincum"), and Attila Gonda (The Aquincum-Salona-Aquileia Triangle: Latin Language in the AlpsDanube-Adria Region) on behalf of the Lendület ('Momentum') Research Group for Computational Latin Dialectology. A talk was given by Silvia Tantimonaco from Universitat de Barcelona ("Applied Computational Latin Dialectology: First Results from the Conventus Pacensis [South Portugal]. Continuity and Linguistic Innovation") as collaborator and data collector of the current Database-project in the framework of a fruitful collaboration established with the University of Barcelona (thanks to Prof. Javier Velaza). Another paper was presented by Daniela Urbanová from Masaryk University Brno ("Latin Curse Texts: Mediterranean Tradition and Local Diversity") representing the vivid collaboration with University of Brno, which yielded six data collectors to the current database-project; the data collectors from Brno were all actively present at the event (as demonstrated below). Further papers were presented by experts invited to the Workshop in hope of a future collaboration; among them were Catarina Gaspar from Universidade de Lisboa ("Constructing, Deconstructing and Understand- 
ing: The Paleo-Christian Corpora and Latin Dialectology") and Dragana Kunčer from The Institute of History, Belgrade ("The Tabella plumbea Traguriensis as Evidence for Spoken Latin in Dalmatia in the $6^{\text {th }}$ Century").

The Workshop was closed by a demo session where the Computerized Historical Linguistic Database of the Latin Inscriptions of the Imperial Age (http://lldb.elte.hu/) and working with the database were demonstrated by Béla Adamik, with the active collaboration of data collectors Markéta Melounová, Natália Gachallová, Pavel Ševčík, Tereza Ševčíková, Radek Černoch and Tomáš Weissar from the University of Brno. (Here I would like to express my gratitude to Irena Radová, chair of the Department of Classical Studies, Faculty of Arts, Masaryk University, Brno, for supporting the participation of the above colleagues). The gist of this demonstration, i.e. the presentation of the search engine and the charting moduls of the current database, has already been published elsewhere, so here it will not be discussed in detail. ${ }^{1}$

The Workshop was dedicated to the memory of József Herman. In justification for that, please find below the welcome speech to the event.

\section{“Dear Colleagues, Dear Friends, Dear Marianne,}

Exactly 10 years ago, in the first half of 2006, we were just developing the software of the Computerized Historical Linguistic Database of the Latin Inscriptions of the Imperial Age, and in the fall of the same year we were able to start recording data. But we shall talk about the Database and the related works tomorrow. Now I would like to say a few words about the background of the project and about the person who inspired this venture. It was József Herman who developed the basic concept of this project at the beginning of the nineties of the twentieth century, when he was the director of this Research Institute for Linguistics of the Hungarian Academy of Sciences where we are now. As an excellent researcher of Vulgar Latin and especially of its territorial aspects in the light of inscriptions, he was completely aware of the lack of and the need for a tool based on modern information technology which could handle and manage the thousands or rather myriads of pieces of inscriptional data otherwise more and more difficult to be handled by traditional methods, i.e. by enumerating and discussing them in printed studies and books, etc. Therefore he founded and developed the Late Latin Data Base with the help of his colleagues at this institute. However, after a promising start, his venture failed, first of all because of the inadequate circumstances of his times as for information technology: particularly the lack of internet at that time was obstructive to his venture. What remained from his Late Latin Data Base afterwards are merely its guidelines for data collection published in 1990 or 1991, which later served for us as a kind of starting point for designing the Database again. Herman did not give up his idea on this very important project after the collapse and the loss of his

${ }^{1}$ ADAMIK, B.: Computerized Historical Linguistic Database of the Latin Inscriptions of the Imperial Age. Search and Charting Modules. In GradvoHL, E. -SzABÓ, Á. (eds.): From Polites to Magos. Studia György Németh Sexagenario Dedicata [Hungarian Polis Studies 22]. Budapest-Debrecen 2016, $13-27$. 
Database, and some years later, in 2004, during the hours of several personal consultations he convinced me that it was worthwhile recreating his former Database, this time on new foundations and in a new format. After successfully applying for financial support to the Hungarian Scientific Research Fund (OTKA) in 2005, we were able to start the development of the new Database renamed as Computerized Historical Linguistic Database of the Latin Inscriptions of the Imperial Age in 2006. Unfortunately, Professor Herman did not live to see the revival of his former Database, since he died prematurely in late 2005. Anyhow, his regrettable death did not hinder the ripening of the fruit of the tree he planted: not only was the Database he had dreamt of realized, but he also changed my professional career entirely. As a researcher of the history of Latin, over the years I turned more and more towards Latin dialectology as observable on inscriptions, since my deeper and deeper involvement in the work with the Database convinced me more and more that Herman's methodology for the dialectological exploitation of Latin inscriptions really does work. Thanks to the work with the Database carried out by a team of collaborators, which now has various members from abroad, impressive results concerning Latin dialectology were obtained and published over the last years. The project, previously run in the framework of the OTKA-project Computerized Historical Linguistic Database of Latin Inscriptions of the Imperial Age, is now carried out in the framework of the Lendület ('Momentum') Research Group for Computational Latin Dialectology, which was founded at the Department of Finno-Ugric and Historical Linguistics of the Institute for Linguistics in 2015, after our successful application to the Hungarian Academy of Sciences. Thanks to this recently founded research group, the First International Workshop on Computational Latin Dialectology could be organized, honouring the memory of my master, József Herman: without his oeuvre and incentive this venture would never have been realized. This is why we came together here with colleagues from abroad, to continue his related work and to carry on his legacy. Thank you all for coming to this event either from my homeland or from abroad, and for contributing to the success of this Workshop. I wish you all a very successful two days, with hopefully rich and positive experiences, and hereby open the First International Workshop on Computational Latin Dialectology."

$* * *$

Hereby I wish to express my gratitude to Marianne Bakró-Nagy, (Chair, Department of Finno-Ugristics and Historical Linguistics, Research Institute for Linguistics, Hungarian Academy of Sciences) for opening the Workshop, to Tamás Adamik and Sándor Kiss (both from Eötvös Loránd University Budapest) for chairing the sessions, to Dániel Seres (Eötvös Loránd University Budapest, data collector in the current Database-project) for his help in editing and producing the programme (http://www.nytud. hu/conf/wcld2016_program_and_abstracts.pdf) and other documents related to the workshop, and, last but not least, to István Kenesei (director of the Research Institute for Linguistics, Hungarian Academy of Sciences) for supporting the Workshop in multiple ways, inter alia by providing the catering while coffee breaks. 
The Workshop was followed by a visit to the Lapidarium of the Hungarian National Museum on Friday, and a visit to the Aquincum Museum and Archeological Park on Saturday. At both locations free entrance was provided by the respective museums, for which I would like to thank Zsolt Mráv and Orsolya Láng.

I wish to express my gratitude to László Takács, chief editor of the Acta Antiqua Academiae Scientiarum Hungaricae for accepting and publishing the following seven papers in the present fascicle of this renowned journal. The papers of a Symposium organized on Linguistics of the Latin Inscriptions in Budapest 2008 (dedicated to the Memory of József Herman), a forerunner of the present Workshop, were also published here back in $2009 .^{2}$

\footnotetext{
Béla Adamik

Lendület ('Momentum') Research Group for Computational Latin Dialectology

Research Institute for Linguistics, Hungarian Academy of Sciences
}

${ }^{2}$ Cf. ADAMIK, B.: Bonae memoriae József Herman: "Du latin épigraphique au latin provincial". Symposium zur Sprachwissenschaft der lateinischen Inschriften. Eötvös-Loránd-Universität Budapest, September 11-12, 2008. ActaAntHung 49 (2009) 1-9, followed by the related papers of B. Adamik (1122), A. Barta (23-29), B. Fehér (31-38), K. Fodor (39-50), G. Galdi (51-67), S. Kiss (69-75), A. Kropp (77-93) and Zs. Ötvös (95-105) in the same fascicle. 